\title{
OCCURRENCE OF Proteus mirabilis ASSOCIATED WITH TWO SPECIES OF VENEZUELAN OYSTERS
}

\author{
Milagro FERNÁndeZ-Delgado(1), Monica CONTRERAS(2), María Alexandra GARCíA-AMAdo(2), Pulchérie GUENEAU(2) \& Paula SUÁREZ(1)
}

\begin{abstract}
SUMMARY
The fecal contamination of raw seafood by indicators and opportunistic pathogenic microorganisms represents a public health concern. The objective of this study was to investigate the presence of enteric bacteria colonizing oysters collected from a Venezuelan touristic area. Oyster samples were collected at the northwestern coast of Venezuela and local salinity, pH, temperature, and dissolved oxygen of seawater were recorded. Total and fecal coliforms were measured for the assessment of the microbiological quality of water and oysters, using the Multiple Tube Fermentation technique. Analyses were made using cultures and 16S rRNA gene sequencing. Diverse enrichment and selective culture methods were used to isolate enteric bacteria. We obtained pure cultures of Gram-negative straight rods with fimbriae from Isognomon alatus and Crassostrea rhizophorae. Our results show that P. mirabilis was predominant under our culture conditions. We confirmed the identity of the cultures by biochemical tests, $16 \mathrm{~S}$ rRNA gene sequencing, and data analysis. Other enterobacteria such as Escherichia coli, Morganella morganii and Klebsiella pneumoniae were also isolated from seawater and oysters. The presence of pathogenic bacteria in oysters could have serious epidemiological implications and a potential human health risk associated with consumption of raw seafood.
\end{abstract}

KEYWORDS: Proteus mirabilis in bivalves molluscan; Isognomon alatus; Crassostrea rhizophorae; Venezuelan coastal area; Public health and environmental impact; Antibiotic resistance.

\section{INTRODUCTION}

After Escherichia coli, Proteus mirabilis ${ }^{10}$ is one of the most frequent etiological agents associated with urinary tract infections (UTIs), particularly in catheterized patients or individuals with structural abnormalities of the urinary $\operatorname{tract}^{17}$. P. mirabilis is a member of the normal microbiota of the mammalian intestinal tract and has been isolated from humans, dogs, monkeys, pigs, sheep, cattle, raccoons, cats, rats, and other mammals ${ }^{7}$. Additionally, $P$. mirabilis is widely distributed in the environment, occurring in polluted water, manure, and soil, where it plays an important role in decomposing organic matter of animal origin ${ }^{16}$. Several potential $P$. mirabilis virulence factors related to UTI have been described, including fimbrial-mediated adherence to the uroepithelium, swarming motility mediated by flagella, outer-membrane protein (OMP) expression, cell invasiveness, urease production, hemolysin production, and iron acquisition ${ }^{16,17}$. Besides UTI, this pathogen has been described as an opportunistic etiological agent in infections of the respiratory tract and of wounds, burns, skin, eyes, ears, nose, and throat, as well as in gastroenteritis resulting from the consumption of contaminated food ${ }^{10,11,16}$.

Proteus is part of predominant microflora in fresh seafood including finfish and shellfish ${ }^{4}$. Also, it has been isolated from tissues and fluid of oysters from a coastal marine environment of Nigeria ${ }^{1}$. Oysters, as filter-feeding organisms, magnify public health problems associated with environmental contamination, because they accumulate microbial pathogens manyfold over the densities found in overlying waters ${ }^{14}$. The fecal contamination of seafood by microorganisms like $P$. mirabilis is one of many major problems of coastal environments indicating a potential human health risk associated with consumption of raw oysters. The objective of this study was to investigate enteric bacteria in oysters collected from a marine coastal area, in view of the popularity of these mollusks as a source of raw food, and to verify sensitivity to antibiotics.

\section{MATERIALS AND METHODS}

Sampling site and sample collection: The first species of oyster (Isognomon alatus, Gmelin, 179120) was collected from a sunken ship close to Chichiriviche, a rural town in northwestern Venezuela $\left(10^{\circ} 18^{\prime} 17^{\prime \prime} \mathrm{N}\right.$ and $\left.68^{\circ} 05^{\prime} 01^{\prime \prime} \mathrm{W}\right)$, during August, October and December 2004. Isognomon alatus was harvested at a depth of half a meter under the water surface over a sunken ship, a place where people dive and collect oysters for raw consumption. Live specimens of the other oyster species (Crassostrea rhizophorae Guilding, 1828 or mangrove oyster ${ }^{8}$ ) were purchased from local fishermen at the nearby town of Chichiriviche $\left(10^{\circ} 55^{\prime} 30^{\prime \prime} \mathrm{N}\right.$ and $\left.68^{\circ} 5^{\prime} 1^{\prime \prime} \mathrm{W}\right)$. Two samples of approximately 60 individuals were collected or purchased from each oyster species, immediately washed with sterile distilled water and

(1) Departamento de Biología de Organismos, Universidad Simón Bolívar, Caracas, Venezuela.

(2) Centro de Biofísica y Bioquímica, Instituto Venezolano de Investigaciones Científicas, Altos de Pipe, Venezuela.

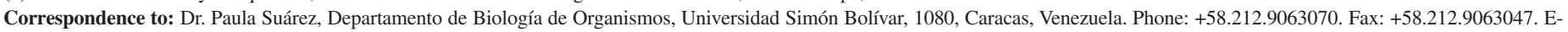
mail: psuarez@usb.ve. 


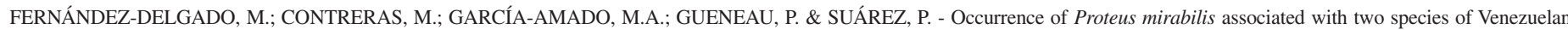
oysters. Rev. Inst. Med. trop. S. Paulo, 49(6): 355-359, 2007.

maintained in separate containers. Samples were transported under refrigeration to the laboratory, where they were processed in fewer than eight hours from capture. Duplicate seawater samples were taken $10 \mathrm{~cm}$ below the surface at the first site and the local values of $\mathrm{pH}$ (pHep1, Hanna Instruments), salinity (RHS-10ATC refractometer, Westover), temperature, and dissolved oxygen (OXDP-02 oxygen meter, VWR) were measured.

Bacteriological quality of water and oyster tissues: The total and fecal coliforms in the samples of seawater and oyster tissue homogenates $(10 \mathrm{~g}$ in $90 \mathrm{~mL}$ PBS buffer $(0.32 \mathrm{M})$ at $\mathrm{pH} 7.2)$ were estimated as the Most Probable Number (MPN) in aliquots of $0.1,1$ and $10 \mathrm{~mL}$. The initial dilutions for this analysis were 1:10 and 1:100, using the Multiple Tube Fermentation (MTF) technique ${ }^{2}$. For the determinations of total coliforms Lauryl Sulfate (Merck) and Bright Green Bile (BRILA, Merck) were used for incubations at $35{ }^{\circ} \mathrm{C}$ for 24-48 h, and the presence of fecal coliforms was confirmed in EC medium (E. coli, Merck) at $44.5^{\circ} \mathrm{C}$ for $24-48$ h. From the dilutions which were positive for total and fecal coliforms, $50 \mu \mathrm{L}$ aliquots were inoculated in MacConkey (HIMEDIA) and ENDO (Merck) media and incubated at $35{ }^{\circ} \mathrm{C}$ for $18-24 \mathrm{~h}$. Isolates from these enteric bacteria were Gram-stained and observed under an optical microscope to aid colony selection and later identification by means of conventional biochemical assays and the API ATB/Plus system (BioMérieux, Lyon, France).

Bacterial isolation from oyster tissue: The oyster shells were first washed thoroughly with sterile water and then opened and the tissues removed; $10 \mathrm{~g}$ of the latter were homogenized 1:10 in PBS buffer $(0.32 \mathrm{M})$ at $\mathrm{pH} 7.2$. Aliquots of $300 \mu \mathrm{L}$ were then inoculated into MacConkey (Difco) and Nutrient Broth (Difco) media, and into the selective Agar Chocolate medium (Blood agar base plates, Difco), supplemented with $10 \%$ sheep blood, and a mixture of antibiotics and fungicides consisting of (final concentrations, per $\mathrm{mL}$ ) vancomycin $(10 \mu \mathrm{g})$, polymyxin B $(2.5 \mathrm{IU})$, trimethoprim $(5 \mu \mathrm{g})$ and amphotericin $\mathrm{B}(2.5 \mu \mathrm{g})$ (Sigma Chem. Co.). These cultures were grown at $37^{\circ} \mathrm{C}$ for 24-48 h.

Biochemical tests and antibiotic resistance: Routine microbiological tests, including those for Gram-stain reaction, oxidase, catalase, urease, arginine dihydrolase, and API ID 32E test (BioMérieux) were performed according to standard methods on all strains ${ }^{2}$. The biochemical characteristics of our isolates were determined with the API ID 32E and API rapid ID 32E systems. A dendrogram based on the API ID 32E biochemical reactions of our isolates was produced with the computer package MINITAB 14.2 (www.minitab.com) by using the single linkage of cluster analysis applied to similarities based on the Manhattan distance. Growth of presumptive Proteus isolates at various salt concentrations and antibiotic resistance patterns were tested in Nutrient Broth (Difco) and Möeller-Hinton Agar (Becton Dickinson), respectively. The Proteus isolates MA (No. 1740) and O (No. 1749) were deposited at the Centro Venezolano de Colecciones de Microorganismos (CVCM, Venezuela).

DNA extraction, PCR and 16S rRNA gene sequencing: Aliquots of the isolates ( $700 \mu \mathrm{L}$ of nutrient broth culture) were placed in sterile Eppendorf tubes and centrifuged at $14,000 \mathrm{~g}$ for one min. The supernatants were discarded and pellets were then stored at $-20{ }^{\circ} \mathrm{C}$ until DNA extraction could be performed. Total genomic DNA was extracted with a MO BIO Laboratories kit (Cat. No. 12224250) used according to the manufacturer recommendations. The 16S rDNA from the isolates was amplified by PCR with puReTaq Ready-To-Go beads (Cat. No. 27-9557-01, Amersham Biosciences, NJ) and two universal primers, 8Fpl (5'- AGA GTT TGA TCC TGG CTC AG -3') and 1525R (5'- AAG GAG GTG ATC CAG CC -3'), derived from highly conserved regions of the $16 \mathrm{~S}$ rRNA genes. Amplification was performed using a thermal cycler model Gen AMP 9700 (Applied Biosystems, CA), as follows: one cycle at $94{ }^{\circ} \mathrm{C}$ for six min, 30 cycles at $94{ }^{\circ} \mathrm{C}$ for $45 \mathrm{~s}, 55$ ${ }^{\circ} \mathrm{C}$ for $45 \mathrm{~s}$ and $72{ }^{\circ} \mathrm{C}$ for one min, with a final $10 \mathrm{~min}$ extension step. The PCR products were visualized by running the reaction mixture in a TBE agarose gel $(2.0 \%)$, staining it with ethidium bromide, and visualizing it under an UV transilluminator. The amplicon was purified for sequencing using the CONCERT ${ }^{\mathrm{TM}}$ Rapid PCR Purification System kit (GibcoBRL-Invitrogen, CA.) according to the manufacturer recommendations. Both strands of the purified DNAs were sequenced at the CeSAAN facility (IVIC, Venezuela) with an ABI PRISM ${ }^{\mathrm{TM}} 377$ sequencer (Perkin-Elmer, USA). The primers used for sequencing were those mentioned above, plus the internal primers 515F (5'- GTG CCA GCM GCC GCG GTA A -3'), 519R (5'- GWA TTA CCG CGG CKG CTG -3'), 926F (5'- GGG CCC GCA CAA GCG GT -3') and 926R (5'- ACC GCT TGT GCG GGC CC -3'). Sequences were compared to the compilation of $16 \mathrm{~S}$ rRNA genes available in the GenBank nucleotide library by BLAST searching through the NCBI site. Alignments of 16S rRNA genes were done manually using EDITVIEW version 1 and bl2seq through the NCBI site. The $16 \mathrm{~S}$ rRNA gene sequence $(\sim 1.4 \mathrm{~kb})$ of isolates MA and $\mathrm{O}$ was deposited in GenBank under the accession numbers DQ449630 and DQ449631, respectively.

\section{RESULTS}

Environmental parameters and bacteriological assessment: At the collecting sites of oysters and during the sampling period the physicochemical parameters of the water were $\mathrm{pH} 8.9$, temperature $29.9^{\circ} \mathrm{C}$, salinity $11 \%$ and dissolved oxygen $4.8 \mathrm{mg} \mathrm{O}_{2} \mathrm{~L}^{-1}$. These values differed from those in dry season at this same location, as salinity and temperature were lowered ${ }^{6}$, possibly due to run-off of rainwater at sampling time. The initial estimates for total and fecal coliforms were 13 and $4 \mathrm{MPN} / 100 \mathrm{~mL}$ in the water and more than 160,000 MPN/g of tissue in both oyster species evaluated for both indicators, confirming the capability of these bivalves to concentrate organic matter and microorganisms.

Characterization of isolates, biochemical tests, and antibiotic resistance: Eleven Enterobacteriaceae were isolated from seawater (Col11), I. alatus (Col13, MA, M4 and M) and C. rhizophorae (Col 15, Col18, Col21, Col22, Col 27 and O) tissue. Results of the biochemical tests and the API ID 32E identification procedure of the $P$. mirabilis isolates obtained from the two species of oysters are in Table 1. Several species were isolated, such as Escherichia coli, Morganella morganii and Klebsiella pneumoniae, as well as $P$. mirabilis which prevailed in both oyster species. All the isolates from P. mirabilis showed biochemical features common to the species (oxidase negative, catalase and urease positive, $\mathrm{H}_{2} \mathrm{~S}$ and lack of indole production and motility). It should be pointed out that the M4 and Col22 isolates grew well at high $\mathrm{NaCl}$ concentrations (6 and 8\%) in less than $48 \mathrm{~h}$ (Table 1$)$. 


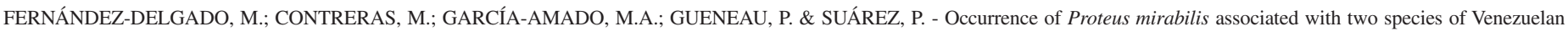
oysters. Rev. Inst. Med. trop. S. Paulo, 49(6): 355-359, 2007.

Table 1

Results of biochemical tests of P. mirabilis isolates from oyster tissue collected from a sunken ship close to Chichiriviche during December 2004

\begin{tabular}{|c|c|c|c|c|c|c|c|c|c|}
\hline \multirow[t]{2}{*}{ Isolates } & \multirow[t]{2}{*}{ Source } & \multirow[t]{2}{*}{ Kliger $^{\mathrm{a}}$} & \multirow[t]{2}{*}{$\operatorname{SIM}^{\mathrm{b}}$} & \multirow{2}{*}{$\begin{array}{c}\text { Citrate }^{\mathrm{c}} \\
\text { (Simmons) }\end{array}$} & \multicolumn{4}{|c|}{$\mathrm{NaCl}$ growth ${ }^{\mathrm{c}, \mathrm{d}}$} & \multirow[t]{2}{*}{ ID 32E Identification } \\
\hline & & & & & $0 \%$ & $3 \%$ & $6 \%$ & $8 \%$ & \\
\hline MA & I. alatus & $\mathrm{K} / \mathrm{A} \mathrm{H}_{2} \mathrm{~S}$ & +-+ & + & + & + & - & - & Proteus mirabilis $(99.9 \%)$ \\
\hline M4 & I. alatus & $\mathrm{K} / \mathrm{A} \mathrm{H}_{2}^{2} \mathrm{~S}$ & +-+ & + & + & + & + & + & Proteus mirabilis $(99.9 \%)^{\mathrm{e}}$ \\
\hline M & I. alatus & $\mathrm{K} / \mathrm{A} \mathrm{H}_{2}^{2} \mathrm{~S}$ & +-+ & + & + & + & - & - & Proteus mirabilis $(99.9 \%)$ \\
\hline $\mathrm{O}$ & C. rhizophorae & $\mathrm{K} / \mathrm{A} \mathrm{H}_{2} \mathrm{~S}$ & +-+ & + & + & + & - & - & Proteus mirabilis $(99.9 \%)$ \\
\hline Col22 & C. rhizophorae & $\mathrm{A} / \mathrm{A} \mathrm{H}_{2} \mathrm{~S}$ & +-+ & + & + & + & + & - & Proteus mirabilis $(99.9 \%)$ \\
\hline
\end{tabular}

${ }^{\mathrm{a}} \mathrm{K} / \mathrm{A}$, alkaline/acid; A/A acid/acid; ${ }^{\mathrm{b}} \mathrm{SIM}: \mathrm{H}_{2} \mathrm{~S}$ and Indole production, and Motility; ${ }^{\mathrm{c}}+$, positive; -, negative; ${ }^{\mathrm{d}}$ Positive results for the $\mathrm{NaCl}$ test were seen at $24 \mathrm{~h}$ for 0 and 3\%, and at $48 \mathrm{~h}$ for 6 and $8 \%$, except in strain Col22 which grew in $6 \% \mathrm{NaCl}$ in $24 \mathrm{~h}$; ${ }^{\mathrm{e}}$ The API rapid ID 32E gallery was used to identify strain M4.

The dendrogram (Fig. 1) shows the biochemical relationships between the isolates and reference microorganisms used at the ID 32 E System strains. The isolates Col22, O, M and MA formed a phenon with $P$. mirabilis (88\% similitude), Col11 with M. morganii $(100 \%)$, Col15, Col18 and Col21 with E. coli $(76 \%)$, and the isolates Col27 and Col13 with K. pneumoniae (92\%). For comparative purposes, Vibrio cholerae was included as a reference strain from outside the Enterobacteriaceae family.

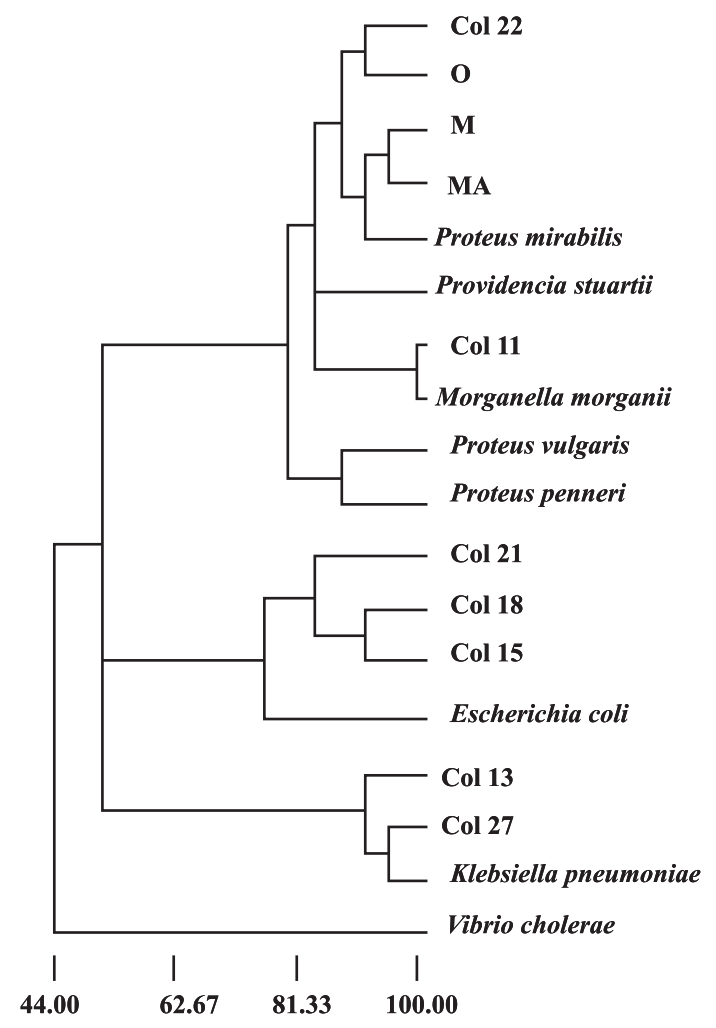

Similarity (\%)

Fig. 1 - Dendrogram based on API ID 32E biochemical reactions showing the levels of similarity between all the isolates (Col 22, O, M, MA, Col 11, Col 21, Col 18, Col15, Col 13, Col 27) and reference microorganisms from the ID 32 E System of Enterobacteriaceae. The graph shows similarity percentages by single-linkage method with Manhattan distances. Strain M4 was not included in this analysis because it had been identified with the API rapid ID $32 \mathrm{E}$ gallery.
The responses of the $P$. mirabilis isolates to diverse therapeutic antibiotics are recorded (Table 2). The Col22 and MA isolates were resistant to seven of the 13 antibiotics evaluated, whereas $\mathrm{O}$ was resistant to only five of them. All isolates were resistant to penicillin $\mathrm{G}$ and to cefoxitin, while being sensitive to quinolones (norfloxacin and lomefloxacin).

Table 2

Antibiotic resistance of P. mirabilis isolates from oyster tissue collected from a sunken ship close to Chichiriviche during December 2004. Concentrations are given per $\mathrm{mL}$

\begin{tabular}{lccccc}
\hline Isolates & MA & M4 & M & O & Col22 \\
\hline Tetracycline $(30 \mu \mathrm{g})$ & $\mathrm{R} *$ & $\mathrm{R}$ & $\mathrm{R}$ & $\mathrm{S}$ & $\mathrm{R}$ \\
Cefoxitin $(30 \mu \mathrm{g})$ & $\mathrm{R}$ & $\mathrm{R}$ & $\mathrm{R}$ & $\mathrm{R}$ & $\mathrm{R}$ \\
Ceftriaxone $(30 \mathrm{mg})$ & $\mathrm{S}$ & $\mathrm{S}$ & $\mathrm{S}$ & $\mathrm{R}$ & $\mathrm{S}$ \\
Cefixime $(5 \mu \mathrm{g})$ & $\mathrm{S}$ & $\mathrm{S}$ & $\mathrm{S}$ & $\mathrm{R}$ & $\mathrm{S}$ \\
Cephradine $(30 \mu \mathrm{g})$ & $\mathrm{I}$ & $\mathrm{I}$ & $\mathrm{I}$ & $\mathrm{S}$ & $\mathrm{R}$ \\
Cefazolin $(30 \mu \mathrm{g})$ & $\mathrm{R}$ & $\mathrm{I}$ & $\mathrm{R}$ & $\mathrm{S}$ & $\mathrm{R}$ \\
Ampicillin $(10 \mu \mathrm{g})$ & $\mathrm{S}$ & $\mathrm{R}$ & $\mathrm{R}$ & $\mathrm{S}$ & $\mathrm{R}$ \\
Penicillin $\mathrm{G}(2 \mathrm{U})$ & $\mathrm{R}$ & $\mathrm{R}$ & $\mathrm{R}$ & $\mathrm{R}$ & $\mathrm{R}$ \\
Ampicillin/sulbactam $(10 \mu \mathrm{g})$ & $\mathrm{R}$ & $\mathrm{R}$ & $\mathrm{R}$ & $\mathrm{S}$ & $\mathrm{R}$ \\
Netilmicin $(30 \mu \mathrm{g})$ & $\mathrm{R}$ & $\mathrm{S}$ & $\mathrm{S}$ & $\mathrm{R}$ & $\mathrm{S}$ \\
Sulfametoxazol-trimethoprim & $\mathrm{R}$ & $\mathrm{R}$ & $\mathrm{S}$ & $\mathrm{S}$ & $\mathrm{S}$ \\
$(10 \mu \mathrm{g})$ & & & & & \\
Norfloxacin $(10 \mu \mathrm{g})$ & $\mathrm{S}$ & $\mathrm{S}$ & $\mathrm{S}$ & $\mathrm{S}$ & $\mathrm{S}$ \\
Lomefloxacina $(10 \mu \mathrm{g})$ & $\mathrm{S}$ & $\mathrm{S}$ & $\mathrm{S}$ & $\mathrm{S}$ & $\mathrm{S}$ \\
\hline
\end{tabular}

* $\mathrm{R}$, resistant $(<5 \mathrm{~mm})$; I, Intermediate $(5-12 \mathrm{~mm})$; $\mathrm{S}$, sensitive (> $12 \mathrm{~mm})$.

Sequencing analyses of $\boldsymbol{P}$. mirabilis isolates: Full 16S rRNA gene sequences were obtained from two bacterial isolates cultured from oyster tissue, MA and $\mathrm{O}$ strains. The 16S rRNA sequences of strains MA and O were highly similar (99\%) to P. mirabilis (GeneBank accession number AF008582). The sequences differed between the isolates by twenty bases (2\%) but they were phenotypically identical, and thus appear to represent the same species.

\section{DISCUSSION}

Our finding reveals the presence of $P$. mirabilis and other bacteria in the tissues of two species, I. alatus and C. rhizophorae. To date, there are rather few reports in the literature concerning the obtainment 


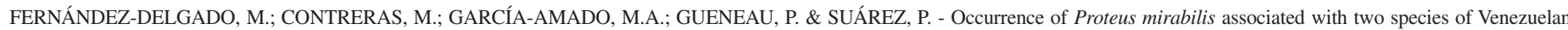
oysters. Rev. Inst. Med. trop. S. Paulo, 49(6): 355-359, 2007.

of $P$. mirabilis from samples of marine invertebrates, especially bivalves ${ }^{5}$; the great majority of isolates come from clinical samples related to urinary tract infections or from feces or intestines of other animals ${ }^{13}$. The presence of $P$. mirabilis in aquatic environments may be attributed to the run-off of contaminated water bodies which increases during rainy periods, and which modifies the physicochemical and perhaps the biological conditions of coastal areas.

The five isolates that were identified as $P$. mirabilis by API ID 32E in our study exhibited differences regarding their tolerance to $\mathrm{NaCl}$. The strains M4 and Col22 withstood high (6\%) $\mathrm{NaCl}$ levels and in particular strain M4 grew well in up to $8 \% \mathrm{NaCl}$ for 24 to $48 \mathrm{~h}$. Hence, M4 may be defined as an halophilic strain and Col22 as an halotolerant strain $^{21}$. Strains $\mathrm{MA}, \mathrm{M}$ and $\mathrm{O}$ grew in $\mathrm{NaCl}$ concentrations from 0 to $3 \%$, in agreement with other reported results showing that $P$. mirabilis strain AF008582 (DSM 4479) grows at levels of about $4 \% \mathrm{NaCl}^{15}$.

By comparing the 16S rRNA gene sequences of our isolates $\mathrm{O}$ and MA, a similitude of $99 \%$ with the P. mirabilis strain AF008582 was found, with differences between 5 to $14 \mathrm{bp}$ from a total of 1451 and $1444 \mathrm{bp}$, respectively. The morphology and the biochemical tests were sufficiently discriminating to confirm the identity of genus and species of the isolates. The API ID 32E has been widely used for the biochemical characterization of enterobacteria and it revealed a considerable variability between the examined isolates (Fig. 1). In particular, the phenon of $P$. mirabilis showed a variation of up to $12 \%$ between isolates and these remained separated according to the source of the samples (I. alatus or C. rhizophorae). Further, the discrimination between the group comprising Proteus-Providencia-Morganella and that of Escherichia-Klebsiella could be clearly seen.

Analyses of resistance to antibiotics in the five isolates from oysters used for the present study showed resistance to tetracycline, penicillins (penicillin G, ampicillin/sulbactam and ampicillin), and cephalosporins (cefoxitin and cefazolin) (Table 2). Comparisons of these results with other reports based on clinical isolates clearly show their similar resistance to tetracyclines. This may be used as an identification marker for this microorganism ${ }^{12}$. However, contrasting with reported susceptibility to penicillins and cephalosporins ${ }^{3,12}$ our isolates were fairly resistant to them. Such differences may be ascribed to strain source, either clinical or environmental, and to serological group ${ }^{9}$. Additionally, halophilic bacteria often show natural resistance to antibiotics. The mechanism behind the resistance remains to be elucidated ${ }^{19}$. We isolated several $P$. mirabilis strains that showed elevated resistance to a wide variety of antibiotics and $\mathrm{NaCl}$. AJAYI \& AKONAI ${ }^{1}$ reported multiple antibiotic resistances on environmental Proteus isolates from a coastal lagoon and their presence indicated recent contamination with sewage which is of significant public health concern. If such microorganisms are consumed by marine organisms, they could spread within the food chain. Similar health and environmental risk could also be occurring in our study area.

To conclude, while $P$. mirabilis is of common occurrence in the human urinary tract, from which it may become an opportunistic pathogen under certain conditions ${ }^{10}$ and spread to diverse environments ${ }^{4,13,18}$, our findings suggest that oysters can accumulate this bacterium. This, in turn, may pose a potential threat to the health of those using these water bodies for recreational purposes and who choose to eat those bivalves raw. Monitoring the microbiological quality of consumable seafood species and commercially important shellfish fisheries should be a priority issue for any public health program.

\section{RESUMO}

\section{Ocorrência de Proteus mirabilis associado a duas espécies de ostras venezuelanas}

A contaminação fecal de frutos do mar crus por microrganismos oportunistas patogênicos representa problema de saúde pública. O objetivo deste estudo é investigar a presença de bactérias entéricas que colonizam ostras coletadas em área turística da Venezuela. Amostras de ostras foram coletadas na costa noroeste da Venezuela e foram registrados a salinidade local, $\mathrm{pH}$, temperatura e o oxigênio dissolvido na água do mar. $\mathrm{O}$ total de coliformes fecais foi medido para a avaliação da qualidade microbiológica da água e das ostras, usando a técnica de fermentação em tubos múltiplos. Análises foram feitas usando culturas e sequiência do gene 16S rRNA. Enriquecimento diversificado e métodos de cultura seletivos foram usados para isolar a bactéria entérica. Obtivemos culturas puras de bastões retos Gram negativos com fímbrias de Isognomon alatus e Crassostrea rhizophorae. Nossos resultados mostram que $P$. mirabilis foi predominante nas nossas condições de cultura. Confirmamos a identidade das culturas por testes bioquímicos, seqüência do gene 16rRNA e a análise de dados. Outras enterobactérias como Escherichia coli, Morganella morganii e Klebsiella pneumoniae foram também isoladas da água do mar e ostras. A presença de bactérias patogênicas em ostras podem ter implicações epidemiológicas e potencial risco para a saúde humana quando do consumo de frutos do mar crus.

\section{ACKNOWLEDGMENTS}

This work was partially funded by FONACIT S1-99000102 and S1-2000006426 grants to P.G and P.S.; a grant from the Instituto Venezolano de Investigaciones Científicas (IVIC) to M.A. G-A, M.C. and P.G. and a grant from the Decanato de Investigación y Desarrollo of the Universidad Simón Bolívar to P.S. The authors gratefully acknowledge Juana Vitelli for the biochemical identification analyses of isolates.

\section{REFERENCES}

1. AJAYI, A.O. \& AKONAI, K.A. - Antibiotic sensitivity profile of microorganisms encountered in the Lagos Lagoon, Nigeria. Afr. J. biomed. Res., 6: 79-84, 2003.

2. AMERICAN PUBLIC HEALTH ASSOCIATION - Standard methods for the examination of water and waste water. Washington, APHA, 1995.

3. CHANAL, C.; BONNET, R.; DE CHAMPS, C. et al. - Prevalence of beta-lactamases among 1,072 clinical strains of Proteus mirabilis: a 2-year survey in a French hospital. Antimicrob. Agents Chemother., 44: 1930-1935, 2000.

4. CHEN, H.C. - Seafood microorganisms and seafood safety. J. Food Drug Anal., 3: 133 $144,1995$.

5. FONTÁNEZ BARRIS, Y. - Determinación del perfil microbiológico de la almeja (Lucina pectinata Gmelin, 1791), del ostión de mangle (Crassostrea rizhophorae Guilding, 1828) y las aguas de extracción de bivalves de la zona suroeste de Puerto Rico. Puerto Rico, 2005. (Maestría - Universidad de Puerto Rico Recinto Universitario Mayagüez). 
6. FUNDACIÓN PARA LA DEFENSA DE LA NATURALEZA - La ostra de mangle: una experiencia comunitaria en la Costa Oriental del Estado Falcón. Venezuela, FUDENA,1999.

7. GUENTZEL, M.N. - Escherichia, Klebsiella, Enterobacter, Serratia, Citrobacter and Proteus. In: BARON, S., ed. Medical Microbiology. New York, Churchill Livingstone, 1991. p. 377-387.

8. INTEGRATED TAXONOMIC INFORMATION SYSTEM - Standard Report URL:http://www.itis.gov/. Accessed in: 27/04/2007.

9. KORNEVA, E.P.; BAIRAMOVA, A.S.; IAKH'EVA, S.A.; SLUTSKII, V.I. \& DANEVICH, M.V. - Resistance to antibiotics of Proteus strains from various sources. Antibiotiki, 29: 263-271, 1984.

10. MANOS, J. \& BELAS, R. - The Genera Proteus, Providencia and Morganella. In: DWORKIN, M., ed. The prokaryotes: an evolving electronic resource for the microbiological community. New York, Springer-Verlag, 2005. URL:http:// link.springer-ny.com/link/service/books/10125/. Accessed in: 07/04/2006.

11. MULLER, H.E. - The role of Proteae in diarrhea. Zbl. Bakt, 272: 30-35, 1989.

12. O'HARA, C.M.; BRENNER, F.W. \& MILLER, J.M. - Classification, identification, and clinical significance of Proteus, Providencia, and Morganella. Clin. Microbiol. Rev., 13: 534-546, 2000.

13. OROS, J.; CALABUIG, P. \& DENIZ, S. - Digestive pathology of sea turtles stranded in the Canary Islands between 1993 and 2001. Vet. Rec., 155: 169-174, 2004.

14. RIPPEY, S.R. - Infectious diseases associated with molluscan shellfish consumption. Clin. Microbiol. Rev., 7: 419-425, 1994.
15. ROESSLER, M.; SEWALD, X. \& MULLER, V. - Chloride dependence of growth in bacteria. FEMS Microbiol. Lett., 225: 161-165, 2003.

16. ROZALSKI, A.; SIDORCZYK, Z. \& KOTELKO, K. - Potential virulence factors of Proteus bacilli. Microbiol. molec. Biol. Rev., 61: 65-89, 1997.

17. SOSA, V.; SCHLAPP, G. \& ZUNINO, P. - Proteus mirabilis isolates of different origins do not show correlation with virulence attributes and can colonize the urinary tract of mice. Microbiology, 152: 2149-2157, 2006.

18. STEELE, C.M.; BROWN, R.N. \& BOTZLER, R.G. - Prevalences of zoonotic bacteria among seabirds in rehabilitation centers along the Pacific Coast of California and Washington, USA. J. Wildl. Dis., 41: 735-744, 2005.

19. TOKUNAGA, H.; MITSUO, K.; ICHINOSE, S. et al. - Salt-inducible multidrug efflux pump protein in the moderately halophilic bacterium Chromohalobacter sp. Appl. environ. Microbiol., 70: 4424-4431, 2004.

20. TURGEON, D.D.; QUINN Jr., J.F.; BOGAN, A.E et al. - Common and scientific names of aquatic invertebrates from the United States and Canada: mollusks. 2. ed. Bethesda, American Fisheries Society, 1998.

21. VENTOSA, A. - Taxonomy of halophilic bacteria. In: DA COSTA M.S.; DUARTE, J.C. \& WILLIAMS, R.A.D., ed. Microbiology of extreme environments and is potential for biotechnology. Cambridge, Elsevier, 1988. p. 262-279.

Received: 16 March 2007

Accepted: 11 June 2007 